\title{
Can needle nitrogen content explain the interspecific difference in ozone sensitivities of photosynthesis between Japanese larch (Larix kaempferi) and Sakhalin fir (Abies sachalinensis)?
}

\author{
T. SUGAI ${ }^{* * * *}$, M. KITAO ${ }^{* *}$, T. WATANABE ${ }^{* * *}$, and T. KOIKE ${ }^{*+}$ \\ Silviculture and Forest Ecological Studies, Graduate School of Agriculture, Hokkaido University, 060-8689 \\ Sapporo, Japan* \\ Hokkaido Research Center, Forestry and Forest Products Research Institute (FFPRI), 7 Hitsujigaoka, 062-8516 \\ Sapporo, Japan ${ }^{* *}$ \\ Plant Nutrition Laboratory, Graduate School of Agriculture, Hokkaido University, 060-8689 Sapporo, Japan ${ }^{* * *}$
}

\begin{abstract}
Although deciduous and evergreen conifers are expected to utilize needle nitrogen differently, their interspecific differences in the ozone sensitivity remain unclear. We compared the growth and physiological responses to elevated $\mathrm{O}_{3}$ concentrations in deciduous Japanese larch (Larix kaempferi) and evergreen Sakhalin fir (Abies sachalinensis) seedlings. Seedlings of both species were exposed to $62.5 \pm 1.95 \mathrm{nmol}\left(\mathrm{O}_{3}\right)$ mol- $^{-1}$ during the day time in open-top chambers. Elevated $\mathrm{O}_{3}$ had no effect on height or diameter growth in either of the species but suppressed photosynthetic parameters. A decline in photosynthetic nitrogen-use efficiency was observed in both species. However, needle $\mathrm{N}$ content in larch was decreased by $\mathrm{O}_{3}$, whereas it was not decreased in fir. Needle $\mathrm{N}$ responses to $\mathrm{O}_{3}$ were different between larch and fir seedlings, indicating that the $\mathrm{O}_{3}$ sensitivity of photosynthesis could vary depending on needle $\mathrm{N}$ dynamics. We also observed a higher correlation between photosynthesis and needle $\mathrm{N}$ even under $\mathrm{O}_{3}$ exposure, particularly in the mass-based relationship with higher accuracy. The result indicated that mass-based needle $\mathrm{N}$ could explain difference in $\mathrm{O}_{3}$ sensitivity of photosynthesis between the different leaf habits in larch and fir seedlings.
\end{abstract}

Additional key words: ozone; deciduous; evergreen; interspecific differences; photosynthetic nitrogen-use efficiency.

\section{Introduction}

Ground-level ozone $\left(\mathrm{O}_{3}\right)$ concentrations have been increasing in Northeast Asia over the last several decades (Akimoto 2017). $\mathrm{O}_{3}$ reduces growth, suppresses photosynthesis, decreases the allocation of photosynthates to roots (which increases the top/root [T/R] ratio), accelerates leaf senescence, and causes a nutritional imbalance in woody species in temperate forests in Northeast Asia (e.g., Koike et al. 2012, Agathokleous et al. 2015, 2017; Kitao et al. 2017, Shi et al. 2017, Sugai et al. 2018).

Previous studies have evaluated several leaf functional traits, which could explain $\mathrm{O}_{3}$ sensitivity in woody species (Bussotti 2008, Zhang et al. 2012, Li et al. 2016, Feng et al. 2018). Among them, leaf mass area (LMA) is strongly associated with the $\mathrm{O}_{3}$ sensitivity of photosynthesis (e.g.,
Hayes et al. 2007, Bussotti 2008, Li et al. 2016, 2017). Compared with other indices of $\mathrm{O}_{3}$ sensitivity, such as stomatal conductance, biogenic volatile organic compound emissions by leaves, LMA is regarded as the most critical index because it is a functional trait that is relatively easy to obtain (Li et al. 2016, Feng et al. 2018). It has also been reported that the thickness of the parenchyma cell layer is highly correlated with antioxidant capacity such as ascorbic acid-equivalent antioxidant capacity (Matyssek et al. 2007, 2008). However, relatively few studies have compared $\mathrm{O}_{3}$ sensitivity between deciduous and evergreen trees based on LMA, particularly in coniferous species (Mortensen 1994, Wieser and Havranek 1996, Watanabe et al. 2006, Weigt et al. 2012).

Another functional trait, a leaf $\mathrm{N}$ content, could explain interspecific differences in the sensitivity of photosynthesis to $\mathrm{O}_{3}$ in coniferous tree species despite leaf $\mathrm{N}$ often being strongly positively correlated with LMA (Niinemets

\footnotetext{
Received 10 August 2018, accepted 6 February 2019.

${ }^{+}$Corresponding author; phone: +81-11-706-3854, e-mail: tkoike@for.agr.hokudai.ac.jp

Abbreviations: $\mathrm{C}_{\text {mass }}$ - carbon content per unit leaf mass; $g_{\mathrm{s}}$ - stomatal conductance per unit leaf area; $g_{\mathrm{sm}}-$ stomatal conductance per unit leaf mass; $J_{\max }$ - maximum electron transport rate; LMA - leaf mass area; $\mathrm{N}_{\text {area }}$ - nitrogen content per unit leaf area; $\mathrm{N}_{\text {mass }}-$ nitrogen content per unit leaf mass; NUE - photosynthetic nitrogen-use efficiency; $P_{\mathrm{N}}$ - net photosynthetic rate per unit leaf area; $P_{\mathrm{Nm}}-$ net photosynthetic rate per unit leaf mass; $P_{\mathrm{Nmax}}-$ net photosynthetic rate at $1,600 \mu \mathrm{mol}\left(\mathrm{CO}_{2}\right) \mathrm{mol}^{-1} ; V_{\text {cmax }}-$ maximum rate of carboxylation. Acknowledgements: This study was supported by a Type B Grant-in-Aid (No. 26292075) from JSPS to T. Koike and innovation study (No. 17K19301) to M. Kitao. The financial source supports of this study are nonprofit organizations.
} 
1999, Kitaoka and Koike 2005). Leaf N content has a strong correlation with photosynthetic capacity including carboxylation capacity and electron transport rate (Hikosaka et al. 2004). A meta-analysis revealed that the mass-based relationship between photosynthesis and leaf $\mathrm{N}$ was always stronger than the area-based relationship (Wright et al. 2004). In addition, deciduous and evergreen conifers are thought to have specific usages of needle $\mathrm{N}$ content, for example, photosynthetic N-use efficiency, leaf N cycling, and storage pools (Small 1972, Reich et al. 1995, Temple et al. 1995, Hikosaka 2004, Takashima et al. 2004, Bussotti 2008, Weigt et al. 2012). Particularly, N demand and turnover in deciduous trees are generally higher than that in evergreen trees (Matyssek 1986). Considering such interspecific differences, we investigated whether leaf $\mathrm{N}$ content could explain the variation in $\mathrm{O}_{3}$ sensitivity of photosynthesis between deciduous and evergreen conifers.

We focused on Japanese larch (Larix kaempferi), a deciduous conifer, and Sakhalin fir (Abies sachalinensis), an evergreen conifer, because the species are ecologically and economically important in northern Japan (Kita et al. 2009, Goto et al. 2011), where $\mathrm{O}_{3}$ tends to be elevated from spring to early summer (Koike et al. 2013, Hatakeyama 2017). Japanese larch is a light-demanding pioneer species and has a high photosynthetic capacity (Ryu et al. 2009). In addition, Japanese larch is a deciduous species that recycles $\mathrm{N}$ from the needles to nonphotosynthetic organs during leaf senescence (Kam et al. 2015). Conversely, Sakhalin fir has a lower photosynthetic capacity and exhibits high shade tolerance, which implies that it utilizes low levels of light, such as those available at the forest floor, more efficiently (Noguchi et al. 2003). In addition, because the fir retains its evergreen needles for 5-10 years or more, depending on the light conditions, it can allocate $\mathrm{N}$ to needles, with $\mathrm{N}$ being continually recycled in some years until the light environment improves (Millard and Proe 1992, Noguchi et al. 2003, Weigt et al. 2012).

In the present study, we compared growth and physiology between Japanese larch and Sakhalin fir seedlings in response to elevated $\mathrm{O}_{3}$. We hypothesized that the negative impacts of $\mathrm{O}_{3}$ on larch would be significant, whereas those on fir would not be significant due to the higher needle $\mathrm{N}$ demand and turnover (Matyssek 1986). We also assessed whether needle $\mathrm{N}$ could be used as an indicator of the $\mathrm{O}_{3}$ sensitivity of photosynthesis in larch and fir seedlings by considering how $\mathrm{O}_{3}$-induced leaf senescence varies between deciduous and evergreen conifers.

\section{Materials and methods}

Study site and plant materials: The experiment was conducted at the Sapporo Experimental Forest of Hokkaido University in northern Japan $\left(43^{\circ} 04^{\prime} \mathrm{N}, 141^{\circ} 20^{\prime} \mathrm{E}, 15 \mathrm{~m}\right.$ a. s. 1.). Two-year-old Japanese larch seedlings were grown from seeds at the nursery of the Hokkaido Research Organization (HRO), Forestry Research Department, Forest Products Research Institute at Bibai near Sapporo. Eight-year-old Sakhalin fir seedlings were obtained from the nursery of the Hokkaido Research Center of Forestry and Forest Products Research Institute (FFPRI),

\section{Sapporo, Japan.}

The larch and fir seedlings were transplanted into 7-L pots on 3 May, 2016, before the buds unfolded. Most of the soil was removed from around roots of the seedlings prior to transplantation to adjust the edaphic conditions, and the pots contained immature volcanic ash soil (Kanuma and Akadama soils, 1:1, v/v). Once the seedlings had completely rooted in the pots, $200 \mathrm{~mL}$ of commercial liquid fertilizer [1:1,000; v/v, HYPONEX, Japan; $72.4 \mathrm{mg}(\mathrm{N}) \mathrm{L}^{-1}$, $\left.284 \mathrm{mg}(\mathrm{P}) \mathrm{L}^{-1}, 94.2 \mathrm{mg}(\mathrm{K}) \mathrm{L}^{-1}\right]$ was applied at 1-2-week intervals as basal dressing to prevent soil desiccation and nutrient imbalance.

Experimental design: Each seedling was exposed to $\mathrm{O}_{3}$ in an open-top chamber (OTC; $1.2 \times 1.2 \times 1.2 \mathrm{~m})$ with a steel frame. Each OTC was surrounded by polyvinyl chloride (PVC) film (Noh-bi Co. Ltd., Sapporo, Japan), which could transmit $88 \%$ sunlight and blocked UVB and UVC radiation. Two $\mathrm{O}_{3}$ treatments were used in the experiments: nonfiltered air that represented the ambient $\mathrm{O}_{3}$ concentration (AOZ) and nonfiltered air enriched with $\mathrm{O}_{3}$ (EOZ). The target concentration of $\mathrm{O}_{3}$ in the EOZ treatment was $60 \mathrm{nmol}\left(\mathrm{O}_{3}\right) \mathrm{mol}^{-1}$ because it is the environmental standard value for the photochemical oxidant in Japan (Ministry of the Environment of Japan, http://www.env.go.jp/kijun/ taiki.html). Each treatment had four replicates for each of the species in separate OTCs, with four seedlings in each of the 16 OTCs (64 seedlings in total).

The OTC system was operated by DALTON Co. Ltd. (Sapporo, Japan). The target $\mathrm{O}_{3}$ concentration was monitored using two devices: the $\mathrm{O}_{3}$ monitor $(2 \mathrm{~B}$ Technologies, NZ) and $\mathrm{O}_{3}$-monitoring system (Ebara, Tokyo, Japan). In the AOZ treatment, ambient air was added to the OTCs, whereas in the EOZ treatment, the target concentration was attained by adding $\mathrm{O}_{3}$ using a generator (Model PZ-1 C, Kofloc, Kyoto, Japan), which employed the pressure swing adsorption method to condense oxygen gas and use it as $\mathrm{O}_{3}$ gas. The $\mathrm{O}_{3}-$ generation method produces only a minimal amount of NOx gas and is environmentally safe. A proportional integrative differential control algorithm was used to maintain the desired $\mathrm{O}_{3}$ concentration. The $\mathrm{O}_{3}$ treatments were applied to the seedlings from 1 June to 3 September, 2016, between 06:00-18:00 h.

The $\mathrm{O}_{3}$ concentrations and environmental conditions in the OTCs are summarized in the following text table. The $\mathrm{O}_{3}$ concentrations that were achieved each month from June to August were $32.9 \pm 1.49,26.9 \pm 1.76$, and $28.3 \pm 1.50 \mathrm{nmol}\left(\mathrm{O}_{3}\right) \mathrm{mol}^{-1}$, respectively, in the $\mathrm{AOZ}$ treatment, and $64.2 \pm 2.31,62.2 \pm 1.68$, and $61.1 \pm 1.85$ nmol $\left(\mathrm{O}_{3}\right) \mathrm{mol}^{-1}$, respectively, in the EOZ treatment. The temperature and light conditions were monitored at 5-min intervals throughout the experimental period using a HOBO Pendant data logger (UA-002-64; Onset Computer Co., MA, USA) that was placed in the center of each OTC above the canopy of the plants.

Leaf gas exchange: Gas-exchange measurements were obtained from the needles of all seedlings on 30 August, 2016. Because the effects of $\mathrm{O}_{3}$ depend on the amount 
Summary of the daily average ozone $\left(\mathrm{O}_{3}\right)$ concentrations at ambient (AOZ) and elevated (EOZ) concentrations, air temperatures, and photosynthetic photon flux densities (PPFDs) in the open-top chambers in June-August 2016. All values are means $\pm \mathrm{SE}$.

\begin{tabular}{lllll}
\hline Parameters & & June & July & August \\
\hline $\mathrm{O}_{3}\left[\mathrm{nmol}\left(\mathrm{O}_{3}\right) \mathrm{mol}^{-1}\right]$ & $\mathrm{AOZ}$ & $32.9 \pm 1.49$ & $26.9 \pm 1.76$ & $28.3 \pm 1.50$ \\
& $\mathrm{EOZ}$ & $64.2 \pm 2.31$ & $62.2 \pm 1.68$ & $61.1 \pm 1.85$ \\
Air temperature $\left[{ }^{\circ} \mathrm{C}\right]$ & & $25.0 \pm 0.39$ & $24.0 \pm 0.56$ & $25.0 \pm 0.39$ \\
$\mathrm{PPFD}\left[\mu \mathrm{mol} \mathrm{m}{ }^{-2} \mathrm{~s}^{-1}\right]$ & & $33.8 \pm 1.46$ & $33.0 \pm 1.82$ & $32.8 \pm 1.62$ \\
\hline
\end{tabular}

absorbed (Wieser et al. 2013, Kitao et al. 2017), it is critical that the same-age needles are used when comparing $\mathrm{O}_{3}$ responses among different foliage types. Therefore, we measured the responses of current-year needles to $\mathrm{O}_{3}$. The gas-exchange rates were measured using an open gas-exchange system (LI-6400; Li-Cor Inc., NE, USA) between 05:00-14:00 h. During measurement, leaf temperature was maintained at $25 \pm 0.5^{\circ} \mathrm{C}$, water vapor deficit in the leaf chamber was approximately $1.2 \pm 0.3 \mathrm{kPa}$, and PPFD was approximately $1,500 \mu \mathrm{mol} \mathrm{m}^{-2} \mathrm{~s}^{-1}$.

In order to determine the net $\mathrm{CO}_{2}$ assimilation rate per intercellular $\mathrm{CO}_{2}$ concentration $\left(P_{\mathrm{N}} / C_{\mathrm{i}}\right)$ curve, $P_{\mathrm{N}}$
[NUE, $\mu \operatorname{mol}\left(\mathrm{CO}_{2}\right) \operatorname{mg}(\mathrm{N})^{-1} \mathrm{~s}^{-1}$ ] using the following equation (Koike et al. 2012): $\mathrm{NUE}=P_{\mathrm{N}} / \mathrm{N}_{\text {area }}$.

Growth: The height and stem basal diameter $(2 \mathrm{~cm}$ from the stem base) of each seedling were measured on 28 May and 29 August, 2016, using a measuring tape (1 mm gradient) and Vernier calipers (Mitsutoyo, Kanagawa, Japan). The diameter was taken as the average of two crosswise measurements at the base of the stem. The initial mean stem diameter and initial mean height $( \pm \mathrm{SE})$ of larch and fir seedlings under $\mathrm{AOZ}$ and $\mathrm{EOZ}$ treatment were as indicated in the following text table:

\begin{tabular}{lllll}
\hline & Larch & & Fir & \\
& AOZ & EOZ & AOZ & EOZ \\
\hline Initial mean stem diameter $[\mathrm{mm}]$ & $5.76 \pm 0.32$ & $5.79 \pm 0.06$ & $10.30 \pm 0.25$ & $9.59 \pm 0.27$ \\
Initial mean height $[\mathrm{cm}]$ & $27.20 \pm 0.15$ & $27.00 \pm 0.40$ & $37.10 \pm 1.02$ & $36.70 \pm 0.87$ \\
\hline
\end{tabular}

was determined at ten concentrations of $C_{\mathrm{i}}\left[C_{\mathrm{a}}: 60-1,600\right.$ $\left.\mu \mathrm{mol}\left(\mathrm{CO}_{2}\right) \mathrm{mol}^{-1}\right]$. The curve was then used to determine $P_{\mathrm{N}}$, the transpiration rate $(E)$, and stomatal conductance $\left(g_{\mathrm{s}}\right)$ at $380 \mu \mathrm{mol}\left(\mathrm{CO}_{2}\right) \mathrm{mol}^{-1} C_{\mathrm{a}}$. The $P_{\mathrm{N}} / C_{\mathrm{i}}$ curve was also used to calculate the maximum net photosynthetic rate at $1,600 \mu \mathrm{mol}\left(\mathrm{CO}_{2}\right) \mathrm{mol}^{-1} C_{\mathrm{a}}\left(P_{\mathrm{Nmax}}\right)$, the maximum rate of carboxylation $\left(V_{\text {cmax }}\right)$, and the maximum rate of electron transport $\left(J_{\max }\right)$ using an individual leaf photosynthetic model (Farquhar et al. 1980, Long and Bernacchi 2003). The $P_{\mathrm{N}} / C_{\mathrm{i}}$ curve was analyzed using values of Rubisco Michaelis constants for $\mathrm{CO}_{2}\left(K_{c}\right)$ and $\mathrm{O}_{2}\left(K_{o}\right)$, and $\mathrm{CO}_{2-}$ compensation point in the absence of dark respiration $\left(\Gamma^{*}\right)$, according to Bernacchi et al. (2001).

Once the photosynthetic measurements had been obtained, the needles were scanned and the projection areas of the needles were measured and converted into a needle area index using the image analysis software ImageJ (National Institutes of Health, Bethesda, Maryland, USA; Schneider et al. 2012).

Leaf elements and photosynthetic $\mathbf{N}$-use efficiency: The needles, which were used for gas-exchange measurements, were collected for further analyses of their $\mathrm{N}$ and carbon (C) contents per unit mass and area $\left(\mathrm{N}_{\text {mass }}, \mathrm{C}_{\text {mass }}\right.$, and $\mathrm{N}_{\text {area, }}$, respectively) and their LMA. Once the needle areas had been measured, the needles were dried at $70^{\circ} \mathrm{C}$ for at least $3 \mathrm{~d}$ until they reached a constant dry mass and were then weighed. $\mathrm{N}_{\text {mass }}$ and $\mathrm{C}_{\text {mass }}$ were measured using an $\mathrm{NC}$ analyzer (VarioEL III; Elementar, Japan). $\mathrm{N}_{\text {area }}$ was then used to calculate the photosynthetic N-use efficiency
Size growth $(\mathrm{Sg})$ in stem diameter and height were calculated by subtracting the initial size value in May from the final size value in August.

Statistical analyses: All statistical analyses were carried out in $R$ version 3.4.3 (R Core Team 2017). Photosynthetic processes at the leaf scale in the two conifer species were compared using a generalized linear mixed model (GLMM). The model included $\mathrm{O}_{3}$ treatment, species, and their interaction as explanatory variables. When a significant interaction effect was detected, Tukey's multiple comparison tests were conducted. GLMM analysis was also used to determine how photosynthetic rate and stomatal conductance were correlated with LMA and needle N. We compared the performance of each model in predicting photosynthetic responses in each species to $\mathrm{O}_{3}$ using Akaike's information criterion (AIC; Akaike 1974). We also used GLMM to evaluate the relationship between photosynthetic parameters, with the influence of leaf traits as the dependent variable and the different species as independent variables. Data from each replicate were averaged, giving four values per species for each treatment $(n=4)$.

\section{Results}

Physiological responses to $\mathbf{O}_{3}$ : Responses of the photosynthetic parameters and needle characteristics of each species to EOZ are summarized in Table 1. There were significant interspecific differences in all the 
Table 1. Photosynthetic and leaf characteristics of the current-year needles of Japanese larch (Larix kaempferi) and Sakhalin fir (Abies sachalinensis). All values are means $\pm \mathrm{SE}(n=4)$ for the ambient (AOZ) and elevated (EOZ) ozone treatments. ${ }^{*}-P<0.05 ;^{* *}-P<0.01$; ${ }^{* * *}-P<0.001$, and n.s. - not significant (GLMM). Different letters within a row indicate significant differences between species (Tukey's multiple comparison test). $P_{\mathrm{N}}$ - net photosynthetic rate at $380 \mu \mathrm{mol}\left(\mathrm{CO}_{2}\right) \mathrm{mol}^{-1}$ and light saturation per unit leaf area; $g_{\mathrm{s}}-$ stomatal conductance per unit leaf area; $P_{\mathrm{Nmax}}-$ net photosynthetic rate at $1,500 \mu \mathrm{mol}\left(\mathrm{CO}_{2}\right) \mathrm{mol}^{-1}$ and light saturation per unit leaf area; $J_{\max }-$ maximum electron transport rate; $V_{\text {cmax }}$ - maximum rate of carboxylation; $\mathrm{N}_{\text {mass }}-$ nitrogen content per unit leaf mass; $\mathrm{C}_{\text {mass }}-$ carbon content per unit leaf mass; $\mathrm{N}_{\text {area }}$ - nitrogen content per unit leaf area; LMA - leaf mass area; NUE - nitrogen-use efficiency.

\begin{tabular}{|c|c|c|c|c|c|c|c|}
\hline \multirow[t]{2}{*}{ Parameters } & \multicolumn{2}{|l|}{ Japanese larch } & \multicolumn{2}{|l|}{ Sakhalin fir } & \multicolumn{3}{|c|}{ GLMM analysis } \\
\hline & $\mathrm{AOZ}$ & $\mathrm{EOZ}$ & $\mathrm{AOZ}$ & $\mathrm{EOZ}$ & $\mathrm{O}_{3}$ & Spp. & $\mathrm{O}_{3} \times \mathrm{Spp}$ \\
\hline$P_{\mathrm{N}}\left[\mu \mathrm{mol}\left(\mathrm{CO}_{2}\right) \mathrm{m}^{-2} \mathrm{~s}^{-1}\right]$ & $6.74 \pm 0.25^{\mathrm{a}}$ & $3.59 \pm 0.10^{c}$ & $4.57 \pm 0.23^{\mathrm{b}}$ & $3.38 \pm 0.17^{c}$ & $* * *$ & $* * *$ & $* * *$ \\
\hline$g_{\mathrm{s}}\left[\mathrm{mol}\left(\mathrm{H}_{2} \mathrm{O}\right) \mathrm{m}^{-2} \mathrm{~s}^{-1}\right]$ & $0.10 \pm 0.01$ & $0.07 \pm 0.01$ & $0.08 \pm 0.01$ & $0.06 \pm 0.01$ & n.s. & $*$ & n.s. \\
\hline$P_{\mathrm{N} \max }\left[\mu \operatorname{mol}\left(\mathrm{CO}_{2}\right) \mathrm{m}^{-2} \mathrm{~s}^{-1}\right]$ & $19.0 \pm 0.68^{\mathrm{a}}$ & $11.7 \pm 0.33^{\mathrm{c}}$ & $14.4 \pm 0.53^{\mathrm{b}}$ & $10.3 \pm 0.3^{\mathrm{c}}$ & $* * *$ & $* * *$ & ** \\
\hline 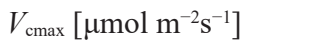 & $60.9 \pm 3.36^{\mathrm{a}}$ & $33.3 \pm 2.66^{\mathrm{bc}}$ & $44.6 \pm 4.48^{b}$ & $28.2 \pm 1.9^{\mathrm{c}}$ & $* * *$ & ** & n.s. \\
\hline$J_{\max }\left[\mu \mathrm{mol} \mathrm{m}{ }^{-2} \mathrm{~s}^{-1}\right]$ & $123 \pm 6.50$ & $72.4 \pm 3.00$ & $106 \pm 11.6$ & $64.3 \pm 4.0$ & $* * *$ & 0.09 & n.s. \\
\hline $\mathrm{N}_{\text {mass }}\left[\mathrm{mg}(\mathrm{N}) \mathrm{g}^{-1}\right]$ & $22.9 \pm 0.61^{\mathrm{a}}$ & $16.1 \pm 0.78^{\mathrm{b}}$ & $15.5 \pm 0.65^{\mathrm{b}}$ & $16.7 \pm 0.5^{\mathrm{b}}$ & $* * *$ & $* * *$ & ${ }^{* * *}$ \\
\hline $\mathrm{C}_{\text {mass }}\left[\mathrm{mg}(\mathrm{C}) \mathrm{g}^{-1}\right]$ & $488 \pm 1.06^{\mathrm{c}}$ & $484 \pm 2.29^{c}$ & $533 \pm 1.66^{\mathrm{b}}$ & $545.0 \pm 0.6^{\mathrm{a}}$ & n.s. & $* * *$ & ${ }^{* * *}$ \\
\hline $\mathrm{N}_{\text {area }}\left[\mathrm{g}(\mathrm{N}) \mathrm{m}^{-2}\right]$ & $1.98 \pm 0.09^{\mathrm{ab}}$ & $1.62 \pm 0.14^{\mathrm{b}}$ & $1.87 \pm 0.12^{\mathrm{ab}}$ & $2.34 \pm 1.61^{\mathrm{a}}$ & * & n.s. & $*$ \\
\hline $\mathrm{LMA}\left[\mathrm{g} \mathrm{m}^{-2}\right]$ & $85.0 \pm 1.28$ & $100 \pm 4.81$ & $121 \pm 4.85$ & $141.0 \pm 5.4$ & $*$ & $* * *$ & n.s. \\
\hline $\mathrm{NUE}\left[\mu \mathrm{mol} \mathrm{g}(\mathrm{N})^{-1} \mathrm{~s}^{-1}\right]$ & $3.59 \pm 0.13$ & $2.85 \pm 0.21$ & $2.53 \pm 0.08$ & $1.45 \pm 0.09$ & $* * *$ & $* * *$ & n.s. \\
\hline
\end{tabular}

photosynthetic parameters (except $J_{\max }$ ), regardless of the $\mathrm{O}_{3}$ treatment. Multiple comparison tests revealed that the fir had significantly lower $P_{\mathrm{N}}$ and $P_{\mathrm{Nmax}}$ values than that of the larch under AOZ, whereas there were no differences in the two parameters between the two species under EOZ. In addition, all the photosynthetic parameters except $g_{\mathrm{s}}$ were significantly inhibited under EOZ in both species.

LMA was significantly higher in the fir than that in the larch regardless of the $\mathrm{O}_{3}$ treatment. However, LMA was also significantly higher under EOZ than that under AOZ. The effects of $\mathrm{O}_{3}$ on $\mathrm{N}_{\text {area }}$ varied between species with multiple comparison tests showing that $\mathrm{N}_{\text {area }}$ was higher in the fir than that in the larch under EOZ. Although area-based differences were not clear in the larch, $\mathrm{N}_{\text {mass }}$ was significantly lower under EOZ than that under AOZ. However, changes in both needle $\mathrm{N}$ parameters were observed in fir under EOZ in the opposite direction, although they were not significant. In addition, a significant, albeit only slight, increase in $\mathrm{C}_{\text {mass }}$ was observed in the fir under EOZ.

Correlation analysis: Correlations between LMA and $P_{\mathrm{N}}$,

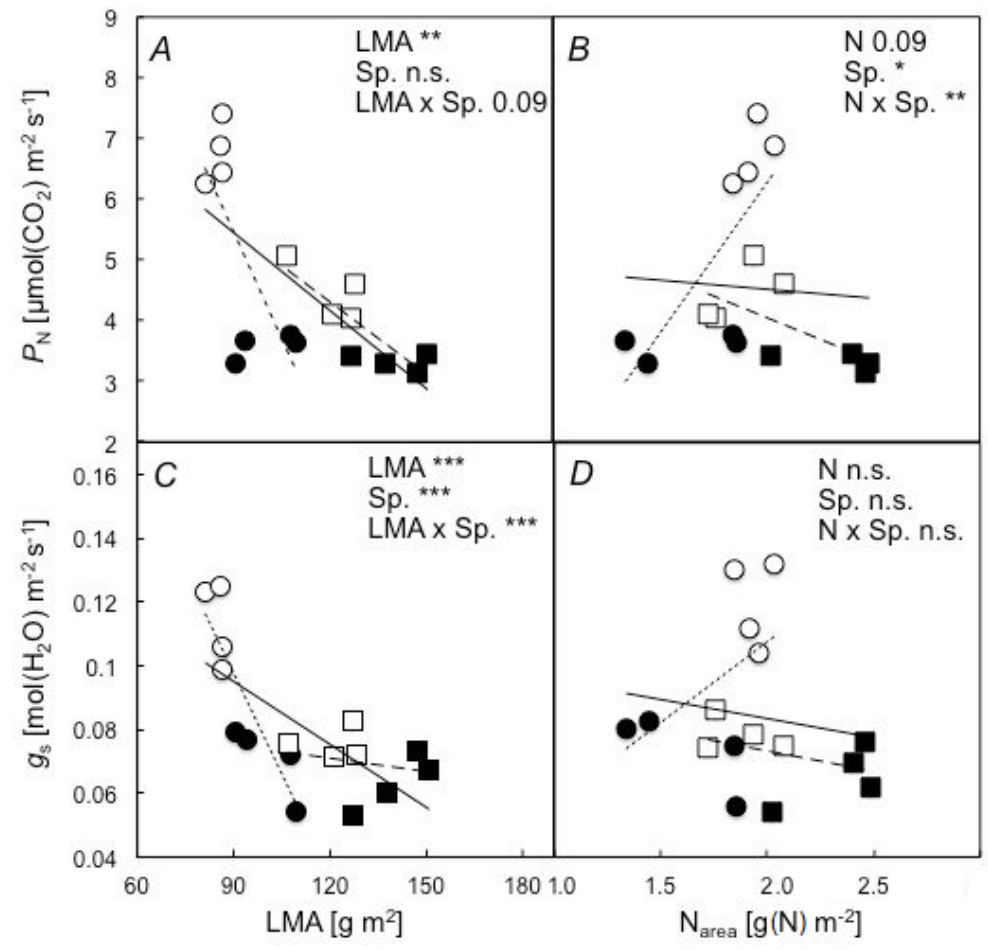

Fig. 1. Relationships between the net photosynthetic rate per unit leaf area at ambient $\mathrm{CO}_{2}$ (i.e., 380 $\left.\mu \mathrm{mol}\left(\mathrm{CO}_{2}\right) \mathrm{mol}^{-1}\right)\left(P_{\mathrm{N}}\right)$ and the leaf mass area (LMA) $(A), P_{\mathrm{N}}$ and the leaf nitrogen per unit area $\left(\mathrm{N}_{\text {area }}\right)(B)$, the stomatal conductance at ambient $\mathrm{CO}_{2}\left(g_{\mathrm{s}}\right)$ and LMA $(C)$, and $g_{\mathrm{s}}$ and $\mathrm{N}_{\text {area }}(D)$ were analyzed with GLMM. Significance: n.s. $-P>0.05 ;{ }^{*}-P<0.05 ;^{* *}-$ $P<0.01$; and ${ }^{* * *}-P<0.001$. Circle and square stands denote Japanese larch (Larix kaempferi) and Sakhalin fir (Abies sachalinensis), respectively. Open and solid stands mean ambient (AOZ) and elevated (EOZ) ozone concentrations, respectively. The relationships between the parameters are indicated by fine dotted lines for Japanese larch, heavy dotted lines for Sakhalin fir, and solid lines for both species. 
Table 2. Summary of the generalized linear mixed models (GLMM) that were developed to explain the relationship between area- and mass-based photosynthetic parameters and morphological and nutritional factors in Japanese larch (Larix kaempferi) and Sakhalin fir (Abies sachalinensis). AIC Akaike's information criterion; $P_{\mathrm{N}}-$ net photosynthetic rate at $380 \mu \mathrm{mol}\left(\mathrm{CO}_{2}\right) \mathrm{mol}^{-1}$ and light saturation per unit leaf area; $g_{\mathrm{s}}-$ stomatal conductance per unit leaf area; $P_{\mathrm{Nm}}-$ net photosynthetic rate at $380 \mu \mathrm{mol}\left(\mathrm{CO}_{2}\right) \mathrm{mol}^{-1}$ and light saturation per unit leaf area; $g_{\text {sm }}$ - stomatal conductance per unit leaf mass; NUE - nitrogenuse efficiency; LMA - leaf mass area; $\mathrm{N}_{\text {area }}$ - nitrogen content per unit leaf area; $\mathrm{N}_{\text {mass }}-$ nitrogen content per unit leaf mass.

\begin{tabular}{|c|c|c|c|}
\hline Model & Adj. $R^{2}$ & $\mathrm{P}$ & AIC \\
\hline \multicolumn{4}{|l|}{ Both conifer species } \\
\hline$P_{\mathrm{N}}=-0.04 \mathrm{LMA}+9.30$ & 0.4766 & 0.003 & 61.35 \\
\hline$P_{\mathrm{N}}=-0.30 \mathrm{~N}_{\text {area }}+5.11$ & 0.0044 & 0.806 & 61.79 \\
\hline$P_{\mathrm{Nm}}=0.06 \mathrm{~N}_{\text {mass }}-0.60$ & 0.7647 & $<0.001$ & -5.61 \\
\hline$g_{\mathrm{s}}=-0.001 \mathrm{LMA}+0.15$ & 0.4864 & 0.003 & -56.02 \\
\hline$g_{\mathrm{s}}=-0.01 \mathrm{~N}_{\text {area }}+0.10$ & 0.0262 & 0.549 & -55.62 \\
\hline$g_{\mathrm{sm}}=0.001 \mathrm{~N}_{\mathrm{mass}}-0.01$ & 0.6575 & $<0.001$ & -115.46 \\
\hline $\mathrm{NUE}=0.16 \mathrm{~N}_{\text {mass }}-0.39$ & 0.4232 & 0.006 & 43.34 \\
\hline \multicolumn{4}{|l|}{ Japanese larch } \\
\hline$P_{\mathrm{N}}=-0.12 \mathrm{LMA}+16.0$ & 0.5123 & 0.003 & 36.89 \\
\hline$P_{\mathrm{N}}=4.94 \mathrm{~N}_{\text {area }}-3.63$ & 0.5146 & 0.045 & 29.38 \\
\hline$P_{\mathrm{Nm}}=0.06 \mathrm{~N}_{\text {mass }}-0.62$ & 0.9005 & $<0.001$ & 1.17 \\
\hline$g_{\mathrm{s}}=-0.002 \mathrm{LMA}+0.31$ & 0.7660 & 0.004 & -18.59 \\
\hline$g_{\mathrm{s}}=0.05 \mathrm{~N}_{\text {area }}+0.01$ & 0.2130 & 0.250 & -18.34 \\
\hline$g_{\mathrm{sm}}=0.001 \mathrm{~N}_{\mathrm{mass}}-0.01$ & 0.7105 & 0.009 & -41.75 \\
\hline $\mathrm{NUE}=0.17 \mathrm{~N}_{\text {mass }}-0.39$ & 0.6663 & 0.013 & 21.77 \\
\hline \multicolumn{4}{|l|}{ Sakhalin fir } \\
\hline$P_{\mathrm{N}}=-0.04 \mathrm{LMA}+9.08$ & 0.6728 & 0.013 & 24.13 \\
\hline$P_{\mathrm{N}}=-1.42 \mathrm{~N}_{\text {area }}+6.90$ & 0.4029 & 0.091 & 20.06 \\
\hline$P_{\mathrm{Nm}}=0.002 \mathrm{~N}_{\text {mass }}+0.283$ & 0.0010 & 0.941 & 2.16 \\
\hline$g_{\mathrm{s}}=-0.0002 \mathrm{LMA}+0.09$ & 0.0454 & 0.607 & -21.35 \\
\hline$g_{\mathrm{s}}=-0.01 \mathrm{~N}_{\text {area }}+0.10$ & 0.1533 & 0.337 & -29.78 \\
\hline$g_{\mathrm{sm}}=-0.0001 \mathrm{~N}_{\text {mass }}+0.01$ & 0.0484 & 0.601 & -51.56 \\
\hline $\mathrm{NUE}=-0.15 \mathrm{~N}_{\text {mass }}+4.33$ & 0.1517 & 0.013 & 23.83 \\
\hline
\end{tabular}

$g_{\mathrm{s}}$ and correlations between $\mathrm{N}_{\text {area }}$ and $P_{\mathrm{N}}, g_{\mathrm{s}}$ are presented in Fig. $1 . P_{\mathrm{N}}$ was more significantly correlated with LMA than with $\mathrm{N}_{\text {area, }}$ with larch having a stronger negative correlation between $P_{\mathrm{N}}$ and LMA than that of fir (Table 2). There was also a strong negative correlation between $g_{\mathrm{s}}$ and LMA in both species, with larch again exhibiting the strongest relationship. By contrast, the correlation between $P_{\mathrm{N}}$ and $\mathrm{N}_{\text {area }}$ varied between species, with a significant positive correlation being observed for larch and a negative relationship being observed for fir. There was no significant correlation between $g_{\mathrm{s}}$ and $\mathrm{N}_{\text {area }}$ in either species.

Correlations between $\mathrm{N}_{\text {mass }}$ and $P_{\mathrm{Nm}}$, and $g_{\mathrm{sm}}$ and NUE are shown in Fig. 2. $P_{\mathrm{Nm}}$ was significantly correlated with $\mathrm{N}_{\text {mass }}$, whereas the correlation between $P_{\mathrm{Nm}}$ and $\mathrm{N}_{\text {mass }}$ was strongest among all models for both species $\left(R^{2}=0.76\right.$; Table 2). The model with the lowest AIC also indicated that the mass-based relationship could explain the $\mathrm{O}_{3}$

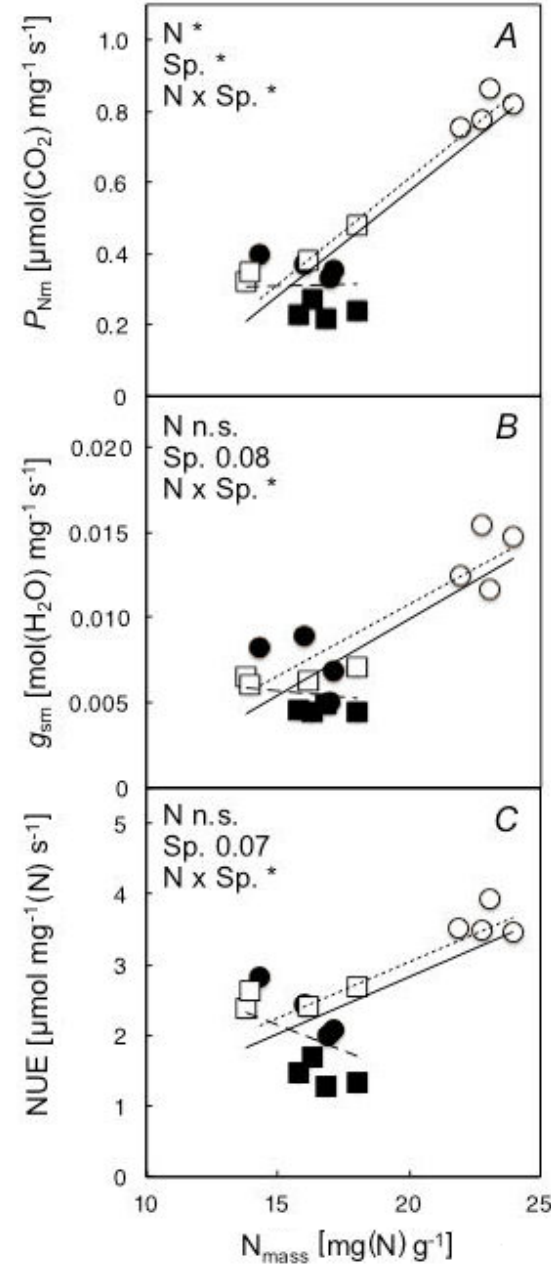

Fig. 2. Relationships between the net photosynthetic rate per unit leaf mass at ambient $\mathrm{CO}_{2}$ (i.e., $\left.380 \mu \mathrm{mol}\left(\mathrm{CO}_{2}\right) \mathrm{mol}^{-1}\right)\left(P_{\mathrm{Nm}}\right)$ and leaf nitrogen per unit mass $\left(\mathrm{N}_{\text {mass }}\right)(A)$, the stomatal conductance per unit leaf mass at ambient $\mathrm{CO}_{2}\left(g_{\mathrm{sm}}\right)$ and $\mathrm{N}_{\text {mass }}(B)$, and the photosynthetic nitrogen-use efficiency (NUE) and $\mathrm{N}_{\text {mass }}(C)$ in the current-year needles of Japanese larch (Larix kaempferi) and Sakhalin fir (Abies sachalinensis) at ambient (AOZ) and elevated (EOZ) ozone concentrations. The relationships between the parameters are indicated by fine dotted lines for Japanese larch, heavy dotted lines for Sakhalin fir, and solid lines for both species.

sensitivity of photosynthesis in each species, despite the correlation not being particularly strong in the fir. The correlation between $g_{\mathrm{sm}}$ and $\mathrm{N}_{\text {mass }}$ was not significant, whereas the relationship varied between species. The correlation between NUE and $\mathrm{N}_{\text {mass }}$ also varied between species with the GLMM analysis revealing that the larch had a stronger positive correlation between NUE and $\mathrm{N}_{\text {mass }}$ than the fir. In addition, the fir had a negative correlation between the two parameters.

Growth response: No significant growth inhibition was observed in either species (Table 3). Moreover, there were no statistical significances in the differences in height and diameter growth within species. 
Table 3. The amounts of size growth ( $\mathrm{Sg}$ ) of a stem diameter and height in Japanese larch (Larix kaempferi) and Sakhalin fir (Abies sachalinensis) under ambient (AOZ) and elevated (EOZ) ozone concentrations. Each Sg was calculated by subtracting the initial size value in May from the final size value in August. All values are means $\pm \operatorname{SE}(n=4)$. n.s. - not significant (Student's $t$-test).

\begin{tabular}{lllllll}
\hline \multicolumn{4}{l}{ Japanese larch } & \multicolumn{2}{l}{ Sakhalin fir } \\
$\mathrm{Sg}$ & $\mathrm{AOZ}$ & $\mathrm{EOZ}$ & $\mid$ T value $\mid$ & AOZ & EOZ & $\mid$ T value $\mid$ \\
\hline Height $[\mathrm{cm}]$ & $6.57 \pm 0.41$ & $4.93 \pm 1.06$ & $1.44^{\text {n.s. }}$ & $7.29 \pm 0.21$ & $6.96 \pm 0.54$ & $0.57^{\text {n.s. }}$ \\
Stem diameter $[\mathrm{mm}]$ & $1.43 \pm 0.20$ & $1.33 \pm 0.22$ & $0.35^{\text {n.s. }}$ & $1.06 \pm 0.25$ & $0.88 \pm 0.22$ & $0.74^{\text {n.s. }}$ \\
\hline
\end{tabular}

\section{Discussion}

In the present study, we compared the physiological and growth responses of Japanese larch and Sakhalin fir seedlings to EOZ. At the leaf scale, significant reductions in photosynthesis under EOZ were observed in both species (Fig. 1, Table 1). However, responses of needle $\mathrm{N}$ content to $\mathrm{O}_{3}$ differed between the two investigated species. A significant reduction in $\mathrm{N}_{\text {mass }}$ under EOZ was observed in Japanese larch (Table 1), whereas it was not observed in Sakhalin fir. However, $\mathrm{N}_{\text {mass }}$ of the studied fir slightly increased by $\mathrm{O}_{3}$ although the difference was not significant. Leaf $\mathrm{N}$ has a strong correlation with photosynthetic capacity because a large fraction of leaf $\mathrm{N}$ content is invested in photosynthetic apparatus (Hikosaka et al. 2004). The $\mathrm{O}_{3}$ responses of photosynthesis in Japanese larch were illustrated by needle $\mathrm{N}$ contents, which is a result that is consistent with those of previous reports (Watanabe et al. 2006, Koike et al. 2012, Wang et al. 2015, Sugai et al. 2018). Previous studies have also reported that $P_{\mathrm{N}}$ in Japanese larch significantly decreased by EOZ, although needle $\mathrm{N}$ content also declined but the difference was not significant. An effect of $\mathrm{O}_{3}$ has also been observed in the form of reduction of $\mathrm{N}$ allocation to protein in leaves (Yamaguchi et al. 2007, 2011), particularly to photosynthetic apparatus (Shang et al. 2018). Based on the results of previous studies, an $\mathrm{O}_{3}$ effect could have suppressed $\mathrm{N}$ allocation to photosynthetic apparatus in Japanese larch in the present study.

Needle N content in Sakhalin fir slightly increased by $\mathrm{O}_{3}$ although the increase was not significant (Table 1). The increase in leaf $\mathrm{N}$ concentration under elevated $\mathrm{O}_{3}$ conditions has also been observed in other evergreen tree species, such as ponderosa pine (Pinus ponderosa; Beyers et al. 1992, Temple et al. 1995), loblolly pine (Pinus taeda; Manderscheid et al. 1992), and camphor laurel (Phoebe bournei; Cao et al. 2016). A potential mechanism of the increase in leaf $\mathrm{N}$ concentration, according to the above studies, is that $\mathrm{O}_{3}$ increased $\mathrm{N}$ availability by increasing protein turnover rate in the senescence-accelerated leaves under EOZ. We hypothesize that the slight $\mathrm{N}$ increment in the fir under study was attributable to $\mathrm{O}_{3}$-induced $\mathrm{N}$ turnover from aged needles, although we did not investigate age-dependent $\mathrm{N}$ dynamics in Sakhalin fir.

The responses of the needle $\mathrm{N}$ contents to $\mathrm{EOZ}$ were different between the species, whereas the NUE responses exhibited similar decreases. The results suggest that the mechanism of NUE reduction could be different between the two investigated species. NUE $\left(P_{\mathrm{N}} / \mathrm{N}_{\text {area }}\right)$ reduction in larch reflected the reduction in $P_{\mathrm{N}}$ relatively more accurately than in $\mathrm{N}_{\text {area }}$ (reduction rates were 46.7 and $18.2 \%$, respectively; Table 1 ). In fir, however, NUE were more accurate in reflecting the reduction in $\mathrm{N}_{\text {area }}$. Although there was no significant difference between the two species, the extent of NUE reduction was relatively higher in the fir than that in larch. The contrasting responses to $\mathrm{O}_{3}$ may be associated with the species-specific utilization of needle N. Larch, which has a deciduous leaf habit, exhibits a higher photosynthetic capacity and recycles $\mathrm{N}$ in needles before shedding, whereas evergreen conifers such as Sakhalin fir generally maintain needle $\mathrm{N}$ for relatively long periods (Millard and Proe 1992, Matsuda et al. 2002, Weigt et al. 2012). Evergreen conifer species also have lower NUE values to facilitate adaptation to resource-poor environments (Reich et al. 1992, 1995) and they could drive sites toward resource-poor conditions by producing litter that does not easily decompose (Reich et al. 1992). Effects of $\mathrm{O}_{3}$, therefore, could have negative effects on fir not only by decreasing NUE but also by introducing N-rich conditions through the increase of needle $\mathrm{N}$ contents. Additional long-term studies focusing on the impacts of $\mathrm{O}_{3}$ on species composition and the ecological $\mathrm{N}$ cycle are required.

Photosynthetic parameters, including $\mathrm{N}_{\text {mass }}$ in both species, were significantly correlated with needle N. The lowest AIC values indicated that $\mathrm{N}_{\text {mass }}$ was the optimal index for explaining photosynthetic parameters in both species (Table 2). We also observed that photosynthetic parameters had a higher correlation with $\mathrm{N}_{\text {mass }}$ than $\mathrm{N}_{\text {area. }}$. The result indicates the overall relationship between photosynthesis and needle $\mathrm{N}$ varies depending on the needle $\mathrm{N}$ unit. Hereafter, we discuss why $\mathrm{N}_{\text {mass }}$ could explain the $\mathrm{O}_{3}$ sensitivity of photosynthesis in conifers with different leaf habits with a greater accuracy. $\mathrm{N}_{\text {mass }}$ has the higher correlation with photosynthesis regardless of species (Hikosaka et al. 2004, Wright et al. 2004). The correlations between photosynthesis and $\mathrm{N}_{\text {area }}$, however, vary depending on species (Field and Mooney 1986, Peterson 1999, Larcher 2003, Matyssek et al. 2005). In addition, generally, photosynthetic rate has a negative correlation with LMA regardless of plant species (Field and Mooney 1986). Our results also supported the hypothesis because the correlation between area-based photosynthetic rate and LMA were negative in both species (Fig. 1). Because of $P_{\mathrm{Nm}}=P_{\mathrm{N}} / \mathrm{LMA}$ and $\mathrm{N}_{\text {mass }}=\mathrm{N}_{\text {area }} /$ LMA, higher NUE values in species result in high $P_{\mathrm{Nm}}$ and $\mathrm{N}_{\text {mass }}$ values, whereas lower NUE values in species result in low $P_{\mathrm{Nm}}$ and $\mathrm{N}_{\text {mass }}$ values. Consequently, the relationship between 
$P_{\mathrm{Nm}}$ and $\mathrm{N}_{\text {mass }}$ has a higher correlation regardless of species (Hikosaka 2004). In the present study, $P_{\mathrm{Nm}}$ had a higher correlation with $\mathrm{N}_{\text {mass }}$ in all treatments, implying that $\mathrm{N}_{\text {mass }}$ was more effective in explaining the $\mathrm{O}_{3}$ sensitivity of photosynthesis in both species. Based on the interactive effects of $\mathrm{N}_{\text {mass }}$ and species, we established that $P_{\mathrm{Nm}}$ and $g_{\text {sm }}$ were clearly independent of $\mathrm{N}_{\text {mass }}$ in the fir (Fig. 2). The result could imply that both parameters were significantly more robust to EOZ in the fir than in the larch. This could have been due to the relatively lower sensitivity to $\mathrm{O}_{3}$ in evergreen trees (Li et al. 2016, 2017). It has previously been reported that there is no relationship between LMA, the apoplastic fraction, and ascorbic acid, which plays a key role in $\mathrm{O}_{3}$ flux in chloroplasts (Niinements 1999, Li et al. 2016). However, there may be other differences at the molecular scale based on antioxidant capacity, stomatal regulation systems, and leaf internal structures (Feng et al. 2018, Shang et al. 2018). Further studies are required to determine the specific mechanism underlying the robustness of mass-based photosynthetic parameters in the fir even under $\mathrm{O}_{3}$ exposure.

In conclusion, photosynthetic responses varied between Japanese larch and Sakhalin fir seedlings under EOZ, which was attributed to different needle $\mathrm{N}$ dynamics. We observed that $\mathrm{N}_{\text {mass }}$ was more effective in explaining the $\mathrm{O}_{3}$ sensitivity of photosynthesis in deciduous and evergreen conifers. Further molecular and anatomical studies are required to reveal the mechanisms underlying the interspecific differences in the $\mathrm{O}_{3}$ sensitivity to between deciduous and evergreen conifers.

\section{References}

Agathokleous E., Saitanis C.J., Koike T.: Tropospheric $\mathrm{O}_{3}$, the nightmare of wild plants: a review study. - J. Agric. Meteorol. 71: 142-152, 2015.

Agathokleous E., Vanderstock A., Kita K., Koike T.: Stem and crown growth of Japanese larch and its hybrid F1 grown in two soils and exposed to two free-air $\mathrm{O}_{3}$ regimes. - Environ. Sci. Pollut. R. 24: 6634-6647, 2017.

Akimoto H.: Overview of Policy Actions and Observational Data for PM2.5 and $\mathrm{O}_{3}$ in Japan: A Study of Urban Air Quality Improvement in Asia. Pp. 19. JICA Research Institute, Tokyo 2017.

Bernacchi C.J., Singsaas E.L., Pimentel C. et al:: Improved temperature response functions for models of Rubisco-limited photosynthesis. - Plant Cell Environ. 24: 253-259, 2001.

Beyers L., Riechers H., Temple J.: Effects of long-term ozone exposure and drought on the photosynthetic capacity of ponderosa pine (Pinus ponderosa Laws.). - New Phytol. 122: 81-90, 1992.

Bussotti F.: Functional leaf traits, plant communities and acclimation processes in relation to oxidative stress in trees: A critical overview. - Glob. Change Biol. 14: 2727-2739, 2008.

Cao J., Shang H., Chen Z. et al.: Effects of elevated ozone on stoichiometry and nutrient pools of Phoebe bournei (Hemsl.) Yang and Phoebe zhennan S. Lee et F. N. Wei seedlings in subtropical China. - Forests 7: 78, 2016.

Farquhar G.D., von Caemmerer S., Berry J.A.: A biochemical model of photosynthetic $\mathrm{CO}_{2}$ assimilation in leaves of $\mathrm{C}_{3}$ species. - Planta 149: 78-90, 1980.

Feng Z., Büker P., Pleijel H. et al.: A unifying explanation for variation in ozone sensitivity among woody plants. - Glob.
Change Biol. 24: 78-84, 2018.

Field C., Mooney H.A.: Photosynthesis-nitrogen relationship in wild plants. - In: Givnish T. (ed.): On the Economy of Plant Form and Function. Pp. 25-55. Cambridge University Press, Cambridge 1986.

Goto S., Iijima H., Ogawa H., Ohya K.: Outbreeding depression caused by intraspecific hybridization between local and nonlocal genotypes in Abies sachalinensis. - Restor. Ecol. 19: 243-250, 2011.

Hatakeyama S.: Aerosols. - In: Izuta T. (ed.): Air Pollution Impacts on Plants in East Asia. Pp. 21-42. Springer, Tokyo 2017.

Hayes F., Jones L.M., Mills G., Ashmore M.: Meta-analysis of the relative sensitivity of semi-natural vegetation species to ozone. - Environ. Pollut. 146: 754-762, 2007.

Hikosaka K.: Interspecific difference in the photosynthesisnitrogen relationship: patterns, physiological causes, and ecological importance. - J. Plant. Res. 117: 481-494, 2004.

Kam D.-G., Shi C., Watanabe M. et al.: Growth of Japanese and hybrid larch seedlings grown under free-air $\mathrm{O}_{3}$ fumigation an initial assessment of the effects of adequate and excessive nitrogen. - J. Agric. Meteorol. 71: 239-244, 2015.

Kita K., Fujimoto T., Uchiyama K. et al.: Estimated amount of carbon accumulation of hybrid larch in three 31-year-old progeny test plantations. - J. Wood Sci. 55: 425-434, 2009.

Kitao M., Yasuda Y., Komatsu M. et al.: Flux based $\mathrm{O}_{3}$ risk assessment for Japanese temperate forests. - In: Izuta T. (ed.): Air Pollution Impacts on Plants in East Asia. Pp. 125-133. Springer, Tokyo 2017.

Kitaoka S., Koike T.: Seasonal and year-to-year variation in light use and nitrogen use of four deciduous broad-leaved tree seedling species invading larch plantations. - Tree Physiol. 25: 467-475, 2005.

Koike T., Mao Q., Inada N. et al.: Growth and photosynthetic responses of cuttings of a hybrid larch (Larix gmelinii var. japonica $\times$ L. kaempferi) to elevated ozone and/or carbon dioxide. - Asian J. Atmos. Environ. 6: 104-110, 2012.

Koike T., Watanabe M., Hoshika Y. et al.: Effects of ozone on forest ecosystems in East and Southeast Asia. - In: Matyssek R., Clarke N., Cudlin P. et al. (ed.): Climate Change, Air Pollution and Global Challenges. Understanding and Perspectives from Forest Research. Pp. 371-390. Elsevier, Oxford 2013.

Larcher W.: Carbon utilization and dry matter production. - In: Larcher W. (ed.): Physiological Plant Ecology: Ecophysiology and Stress Physiology of Functional Groups. Pp. 69-184. Springer, Berlin-Heidelberg 2003.

Li P., Calatayud V., Gao F. et al.: Differences in ozone sensitivity among woody species are related to leaf morphology and antioxidant levels. - Tree Physiol. 36: 1105-1116, 2016.

Li P., Feng Z., Catalayud V. et al.: A meta-analysis on growth, physiological, and biochemical responses of woody species to ground-level ozone highlights the role of plant functional types. - Plant Cell Environ. 40: 2369-2380, 2017.

Long S.P., Bernacchi C.J.: Gas exchange measurements, what can they tell us about the underlying limitations to photosynthesis? Procedures and sources of error. - J. Exp. Bot. 54: 2393-2401, 2003.

Manderscheid R., Jager H.-J., Kress L.W.: Effects of ozone on foliar nitrogen metabolism of Pinus taeda L. and implications for carbohydrate metabolism. - New Phytol. 121: 623-633, 1992.

Matsuda K., Shibuya M., Koike T.: Maintenance and rehabilitation of the mixed conifer-broadleaf forests in Hokkaido, Northern Japan. - Eurasian J. Forest Res. 5: 119-130, 2002.

Matyssek R.: Carbon, water and nitrogen relations in evergreen 
and deciduous conifers. - Tree Physiol. 2: 177-187, 1986.

Matyssek R., Agerer R., Ernst D. et al.: The plant's capacity in regulating resource demand. - Plant Biol. 7: 560-580, 2005.

Matyssek R., Bytnerowicz A., Karlsson P.E. et al.: Promoting the $\mathrm{O}_{3}$ flux concept for European forest trees. - Environ. Pollut. 146: 587-607, 2007.

Matyssek R., Sandermann H., Wieser G. et al.: The challenge of making ozone risk assessment for forest trees more mechanistic. - Environ. Pollut. 146: 587-607, 2008.

Millard P., Proe M.F.: Storage and internal cycling of nitrogen in relation to seasonal growth of Sitka spruce. - Tree Physiol. 10: 33-43, 1992.

Mortensen L.M.: The influence of carbon dioxide or ozone concentration on growth and assimilate partitioning in seedlings of nine conifers. - Acta Agr. Scand. B-S. P. 44: 157163, 1994.

Niinements Ü.: Components of leaf dry mass per area - thickness and density - alter leaf photosynthetic capacity in reverse directions in woody plants. - New Phytol. 144: 35-47, 1999.

Noguchi M., Kayama M., Yoshida T., Koike T.: [Photosynthetic traits of seedlings of Sakhalin fir grown under selective cutting in a fir forest.] - Transactions of the Meeting in Hokkaido Branch of the Japanese Forest Society 51: 36-38, 2003. [In Japanese]

Peterson A.G.: Reconciling the apparent difference between mass-and area-based expressions of the photosynthesisnitrogen relationship. - Oecologia 118: 144-150, 1999.

R Core Team: R: A Language and Environment for Statistical Computing. R Foundation for Statistical Computing, Vienna 2017. https://www.R-project.org

Reich P.B., Walters M.B., Ellsworth D.S.: Leaf life-span in relation to leaf, plant and stand characteristics among diverse ecosystems. - Ecol. Monogr. 62: 365-392, 1992.

Reich P.B., Walters M.B., Kloeppel B.D., Ellsworth D.S.: Different photosynthesis-nitrogen relations in deciduous hardwood and evergreen coniferous tree species. - Oecologia 104: 24-30, 1995.

Ryu K., Watanabe M., Shibata H. et al.: Ecophysiological responses of the larch species in northern Japan to environmental changes as a basis for afforestation. - Landsc. Ecol. Eng. 5: 99-106, 2009.

Schneider C.A., Rasband W.S., Eliceiri K.W.: NIH Image to ImageJ: 25 years of image analysis. - Nat. Methods 9: 671675, 2012.

Shang B., Xu Y., Dai L., Feng Z.: Elevated ozone reduced leaf nitrogen allocation to photosynthesis in poplar. - Sci. Total Environ. 657: 169-178, 2018.

Shi C., Watanabe T., Koike T.: Leaf stoichiometry of deciduous tree species in different soils exposed to free-air $\mathrm{O}_{3}$ enrichment over two growing seasons. - Environ. Exp. Bot. 138: 148$163,2017$.

Small E.: Photosynthetic rates in relation to nitrogen recycling as an adaptation to nutrient deficiency in peat bog plants. - Can. J. Bot. 50: 2227-2233, 1972.

Sugai T., Kam D.G., Agathokleous E. et al.: Growth and photosynthetic response of two larches exposed to $\mathrm{O}_{3}$ mixing ratios ranging from preindustrial to near future. Photosynthetica 56: 901-910, 2018.

Takashima T., Hikosaka K., Hirose T.: Photosynthesis or persistence: Nitrogen allocation in leaves of evergreen and deciduous Quercus species. - Plant Cell Environ. 27: 10471054, 2004.

Temple P., Riechers G.: Nitrogen allocation in ponderosa pine seedlings exposed to interacting ozone and drought stresses. New Phytol. 130: 87-104, 1995.

Wang X., Qu L., Mao Q. et al.: Ectomycorrhizal colonization and growth of the hybrid larch $\mathrm{F} 1$ under elevated $\mathrm{CO}_{2}$ and $\mathrm{O}_{3}$.Environ. Pollut. 197: 116-126, 2015.

Watanabe M., Yamaguchi M., Iwasaki M. et al.: Effects of ozone and/or nitrogen load on the growth of Larix kaempferi, Pinus densiflora and Cryptomeria japonica seedlings. - J. Japan Soc. Atmos. Environ. 41: 320-334, 2006.

Weigt R.B., Haberle K.H., Millard P. et al.: Ground-level ozone differentially affects nitrogen acquisition and allocation in mature European beech (Fagus sylvatica) and Norway spruce (Picea abies) trees. - Tree Physiol. 32: 1259-1273, 2012.

Wieser G., Havranek M.: Evaluation of ozone impact on mature spruce and larch in the field. - J. Plant Physiol. 148: 189-194, 1996.

Wieser G., Hecke K., Tausz M., Matyssek R.: Foliage type specific susceptibility to ozone in Picea abies, Pinus cembra and Larix decidua at treeline: A synthesis. - Environ. Exp. Bot. 90: 4-11, 2013.

Wright J., Reich P.B., Westoby M. et al.: The worldwide leaf economics spectrum. - Nature 428: 821-827, 2004.

Yamaguchi M., Watanabe M., Iwasaki M. et al.: Growth and photosynthetic responses of Fagus crenata seedlings to $\mathrm{O}_{3}$ under different nitrogen loads. - Trees 21: 707-718, 2007.

Yamaguchi M., Watanabe M., Matsumura H. et al.: Experimental studies on the effects of ozone on growth and photosynthetic activity of Japanese forest tree species. - Asian J. Atmos. Environ. 5: 65-78, 2011.

Zhang W., Feng Z., Wang K., Niu F.: Responses of native broadleaved woody species to elevated ozone in subtropical China. - Environ. Pollut. 163: 149-157, 2012.

(C) The authors. This is an open access article distributed under the terms of the Creative Commons BY-NC-ND Licence. 